(RESEARCH ARTICLE)

\title{
Investigation of plants with ethnobotanical use in Gaziantep province (Turkey)
}

\author{
Özer Havva ${ }^{1}$ and Türkmen Necattin ${ }^{2, *}$ \\ ${ }^{1}$ Republic of Turkey, Credit and Hostels Institution, Regional Representative, Adana-Turkey. \\ ${ }^{2}$ Cukurova University, Faculty of Sciences and Letters, Department of Biology, 01330 Adana-Turkey.
}

Publication history: Received on 19 April 2019; revised on 13 May 2019; accepted on 15 May 2019

Article DOI: https://doi.org/10.30574/gscbps.2019.7.2.0076

\begin{abstract}
This research was carried out to determine the ethnobotanical use of natural and cultural plants used by local people living in the rural areas of Gaziantep province. The research was conducted in 2013-2016. As a result of interviews made with the people of the region, 65 plant species belonging to 59 genera and 24 families were identified. Families with the most species in terms of use: Asteraceae (10 species), Rosaceae (10 species), Brassicaceae (6 species), Lamiaceae (6 species), Anacardiaceae (3 species), Apiaceae (3 species), Liliaceae (3 species) and Moraceae (3 species). The proportion of wild plant species to total species in the study area is $60 \%$ (39 species). It was determined that these plant species were used for various purposes (food, medicinal, spices, tea, chewing gum, toothpicks, textile, amulet, and fodder). The wild medicinal plants sold must be cultured to ensure standardization and the medicinal plant sellers should be adequately trained.
\end{abstract}

Keywords: Gaziantep; Ethnobotany; Useful plants; Medicinal plants; Turkey

\section{Introduction}

The ethnobotanical term was first described by John W. Harshberger, a professor of biology in 1896, to refer to the investigation of the natural history of local people and was described as "the use of plants in the local community" [1, 2]. Today, however, not only are the plants used, but they also focus on issues such as how to understand why and how they are used, the conditions of the environment in which these plants grow and cultivation [3].

Ethnobotany deals with the obligate dynamic relationships interactions between human population, cultural values and plants. However, the interaction of plants with human society changes due to their uses, relative importance, variations in social, cultural and ethnic factors [4]. Turkey has rich history on the folk use of plants. Some ethnobotanical studies have been documented the medicinal knowledge about the plants in different parts of the country $[5,6,7]$.

Investigations on cultivated plants have shown that the use of dense fertilizers and chemical medicines negatively affects the natural flavors and aromas of plants. Hence, interest in organic crops and naturally grown wild plants is increasing. Due to the ineffectiveness of synthetic drugs over time and the increased side effects, the tendency towards plant-based therapies has increased [4].

According to the World Health Organization (WHO), about 20,000 plant species are used for medical purposes. The main commercial centers of herbal medicines in the world are Hamburg, New York and Hong Kong. Today, ethnobotanical studies include not only medical plants but also food, handicrafts, fuel, animal feed, coloring, veterinary medicine, etc. Over time, ethnobotanical work has gained momentum as the global environmental crisis has grown and traditional botany culture has disappeared [8].

\footnotetext{
${ }^{*}$ Corresponding author

E-mail address: nturkmen@cu.edu.tr
} 
Gaziantep province, which is a research area, is located at the junction of Mediterranean and Southeastern Anatolia and is located between $36^{\circ} 28$ 'and $38^{\circ} 01^{\prime}$ ' east longitudes and $36^{\circ} 38$ 'and $37^{\circ} 32^{\prime}$ north latitudes. Gaziantep, with 6,222 square kilometers area covers about 1\% part of Turkey (Fig. 1). Gaziantep which has a history of 6000 years is one of the oldest settlements of Anatolia and the World. The population of the city is over 2 million with the immigrations it took in recent years.

Gaziantep is rich in biodiversity because it covers the Mediterranean and Iran-Turan vegetation geographical regions. Forests and shrubs in the western part are from Mediterranean plants, and the steppe species in the eastern and southern parts are composed of Iran-Turan plants. There is no extensive ethnobotanical work already done in Gaziantep which has rich plant diversity. Therefore, this work was done to record the majority of domestic medical plants and other traditional ethnobotanical information.

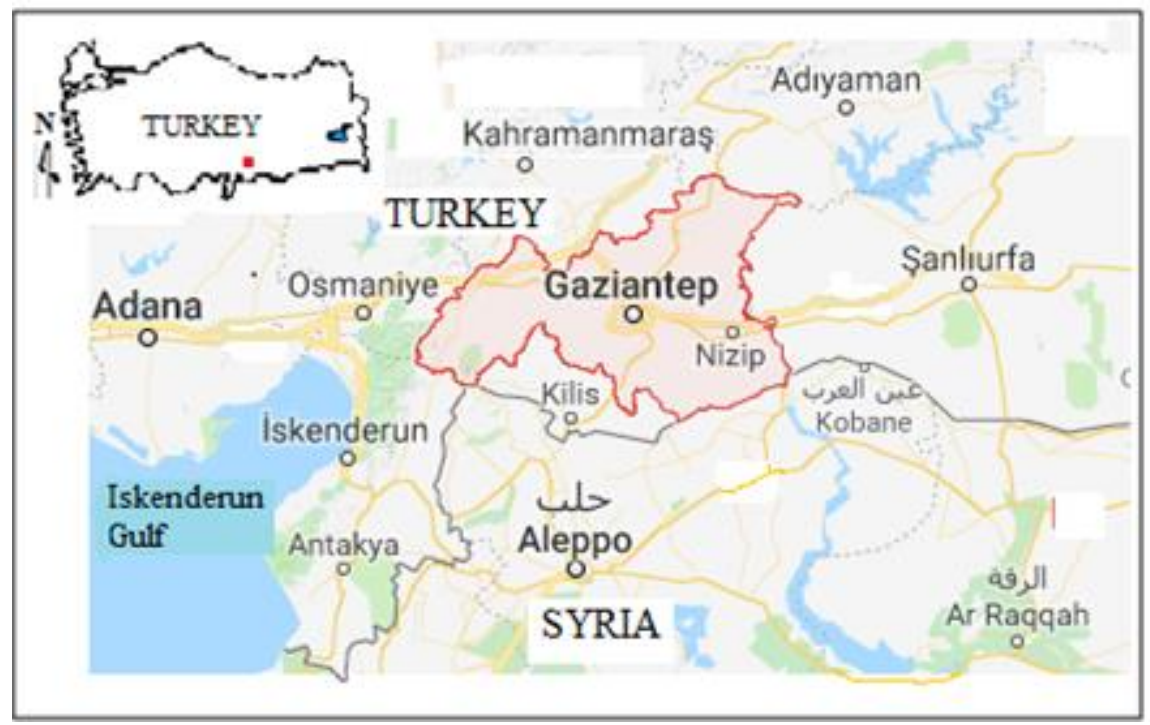

Figure 1 Geographic location of the study area (modified from Google Earth)

\section{Material and methods}

Many visits were made to the study area in different seasons between 2013 and 2016. Ethnobotanical data including local names and traditional uses of the plants was obtained from local inhabitants (informants) including both males and females preferably of old ages through semi-structured questionnaire [2]. During the surveys, new samples of useful plants were collected with the guidance of local inhabitants from the study area for voucher specimens and scientific identification. The photos of the plants collected were taken.

All collected samples were identified according to the Flora of Turkey [9]. Author names of plant species were written according to Brummitt and Powell [10].

\section{Results and discussion}

As a result of field studies and surveys in Gaziantep region, a total of 65 vascular plant species (belonging to 59 genera and 26 families) with ethnobotanical use were determined. All of these species belong to the Spermatophyta section and Angiospermae (Flowering Plants) class. Of these, 39 (60\%) are naturally grown and 26 (40\%) are traditionally cultivated species. Their families, their local and scientific names, their intended use, their form of use and their parts are given in Table 1. 
Table 1 Floristic list and traditional use of plants found in Gaziantep Province, Turkey

\begin{tabular}{|c|c|c|c|c|}
\hline Family / Species & Local name & Traditional uses & Parts used & Usefulness-Aplication; Naturalness \\
\hline \multicolumn{5}{|l|}{ Anacardiaceae } \\
\hline Pistacia terebinthus L. & Melengiç & Food, medicinal & Fruit & Roasted coffee is used in the treatment of sore throat; wild \\
\hline Pistacia vera $\mathrm{L}$. & Antep fistığl & Food, medicinal & Fruit & $\begin{array}{l}\text { It is consumed fresh and dry, it is used in treatment of stomach } \\
\text { aches by swallowing gum; culture }\end{array}$ \\
\hline Rhus coriaria L. & Sumak & Spice & Fruit & It is consumed as sour spices; wild \\
\hline \multicolumn{5}{|l|}{ Apiaceae } \\
\hline Ammi visnaga (L.) Lam. & Hiltan & Toothpick & Pedicels & Used in drying; culture \\
\hline Coniumm maculatum $\mathrm{L}$. & Baldırgan & Medicinal & Aerial parts & $\begin{array}{l}\text { It is made into ointment by crushing, it is used in itching } \\
\text { treatment.; wild }\end{array}$ \\
\hline Petroselinum crispum (Mill.) A.W.Hill & Maydanoz & Food, medicinal & $\begin{array}{l}\text { Leaves, } \\
\text { stem }\end{array}$ & $\begin{array}{l}\text { Freshly eaten in salads and meals, the tea is used in the } \\
\text { treatment of kidney stones; culture }\end{array}$ \\
\hline \multicolumn{5}{|l|}{ Asteraceae } \\
\hline Anthemis pseudocotula Boiss. & Papatya, dövmecik & Spice & Stem & Dried and used as spice in meatballs; wild \\
\hline Carduus nutans L. & Alagelek & Food & Leaves & Used in making pilaw; wild \\
\hline Centaurea babylonica (L.) L. & Kavkut & Food & Stem & The body is peeled and consumed raw; wild \\
\hline Centaurea calcitrapa $\mathrm{L}$. & Çakırdikeni & Food & Stem & The body is peeled and consumed raw; wild \\
\hline Gundelia tournefortii L. & Sakız kenger & $\begin{array}{l}\text { Food, chewing } \\
\text { gum }\end{array}$ & Stem, root & $\begin{array}{l}\text { Body shell is peeled and eaten fresh; chewing gum is obtained } \\
\text { from its roots; wild }\end{array}$ \\
\hline Lactuca sativa L. & Marul & Food & Leaves & Consumed as a salad; culture \\
\hline $\begin{array}{l}\text { Onopordum carduchorum Bornm. et } \\
\text { Beauverd }\end{array}$ & Kenger & Food & $\begin{array}{l}\text { Flower } \\
\text { table }\end{array}$ & The flower table is eaten by removing the thorns; wild \\
\hline Scorzonera kotschyi Boiss. & Yemlik & Food & Leaves & Freshly eaten; wild \\
\hline Silybum marianum (L.) Gaertn. & Kangal & Food & Stem & Peeled and eaten; wild \\
\hline $\begin{array}{l}\text { Tragopogon longirostis Bisch. ex } \\
\text { Schultz Bip. }\end{array}$ & Tekesakalı & Food & Leaves & Freshly eaten; wild \\
\hline \multicolumn{5}{|l|}{ Boraginaceae } \\
\hline Anchusa azurea Mill. & Dingilkara & Medicinal & Aerial parts & The mash formed by boiling is applied to wound surface; wild \\
\hline Onosma albo-roseum Fisc. et Mey. & Emecek & Food & Flower & The nectar in the flower is eaten by the children; wild \\
\hline \multicolumn{5}{|l|}{ Brassicaceae } \\
\hline Cardaria draba (L.) Desv. & Bozot-Toklubaşı & Food & Leaves & Used in making pilaw; wild \\
\hline Coronopus squamatus (Forssk.) Asch. & Yaban teresi & Food & Aerial parts & A fresh salad is made; wild \\
\hline Erysimum smyrnaeum Boiss. et Balansa & Büzmecik otu & Medicinal & Flowers & Boiled tea is used in children to treat jaundice; wild \\
\hline Nasturtium officinale R. Br. & Ispatan & Food & Aerial parts & Freshly eaten; wild \\
\hline Raphanus sativus L. & Turp & Food & Root, leaves & Freshly eaten, culture. \\
\hline Sinapis arvensis L. & Hardal & Food & Seed & Pilaf is made; wild \\
\hline
\end{tabular}




\begin{tabular}{|c|c|c|c|c|}
\hline \multicolumn{5}{|l|}{ Cucurbitaceae } \\
\hline Bryonia alba L. & $\begin{array}{l}\text { Yilan kökü, } \\
\text { ürüngül }\end{array}$ & Food & Aerial parts & Roasted eaten; wild \\
\hline \multicolumn{5}{|l|}{ Fabaceae } \\
\hline Cicer arietinum L. & Nohut & Food & Fruit & Eaten as dry and fresh; culture \\
\hline \multicolumn{5}{|l|}{ Geraniaceae } \\
\hline Erodium cicutarium (L.) L'Hér. & İğnelik & Food & Aerial parts & Roasted with onions, eaten; wild \\
\hline \multicolumn{5}{|l|}{ Hypericaceae } \\
\hline Hypericum perforatum L. & Kantaron & Medicinal & Flower & $\begin{array}{l}\text { The mixture obtained by holding for } 1 \text { year in olive oil is used } \\
\text { in all kinds of wound treatment; wild }\end{array}$ \\
\hline \multicolumn{5}{|l|}{ Juglandaceae } \\
\hline Juglans regia $\mathrm{L}$. & Ceviz & Food & Fruit & Eat as nuts, culture \\
\hline \multicolumn{5}{|l|}{ Lamiaceae } \\
\hline Melissa officinalis L. & İğne otu & Medicinal & Leaves & $\begin{array}{l}\text { The tea is used in the treatment of insomnia by its relaxing } \\
\text { effect.; wild }\end{array}$ \\
\hline Mentha longifolia (L.) Huds. & Yarpuz & Food & Aerial parts & Used in making fresh salads; wild \\
\hline Mentha piperita L. & Nane & Food & Aerial parts & Used in making fresh and dry salads; wild \\
\hline Sideritis syriaca L. & Dağ çayı-Balbaşı & Tea-making & Aerial parts & Drinked as tea; wild \\
\hline Teucrium polium L. & Acl yavşan & Medicinal & Aerial parts & The tea is consumed as a gas remover in babies; wild \\
\hline Thymbra spicata L. & Zahter & Spice, tea-making & Leaves & It is consumed as spice and tea; wild \\
\hline \multicolumn{5}{|l|}{ Liliacae } \\
\hline Allium cepa L. & Soğan & Food & Aerial parts & Used in meals; culture \\
\hline Allium sativum $\mathrm{L}$. & Sarımsak & Food & Aerial parts & Used in meals; culture \\
\hline Asphodelus aestivus Brot. & Nünnük & Food & Leaves & Roasted eaten; wild \\
\hline \multicolumn{5}{|l|}{ Malvaceae } \\
\hline Alcea setosa (Boiss.) Alef. & Hira & Medicinal & Flower & Tea is used to cough; wild \\
\hline Gossypium herbaceum L. & Pamuk & Textile & Seed hairs & Seed hairs are used in the textile industry; culture \\
\hline Malva neglecta Wallr. & Döngel & Food & $\begin{array}{l}\text { Leaves, } \\
\text { stem }\end{array}$ & Boil it with hot water and make salad; wild \\
\hline \multicolumn{5}{|l|}{ Moraceae } \\
\hline Ficus carica L. & İncir & Food & Fruit & $\begin{array}{l}\text { Eat fruit; a kind of yoghurt called 'teleme' is obtained with } \\
\text { milk; culture }\end{array}$ \\
\hline Morus alba L. & Beyaz dut & Food & Fruit & The fruit is eaten fresh and dry; culture \\
\hline Morus nigra L. & Kara dut & Food, medicinal & Fruit & $\begin{array}{l}\text { The fruit is eaten fresh, crushed and used in the treatment of } \\
\text { oral wounds; culture }\end{array}$ \\
\hline \multicolumn{5}{|l|}{ Oleaceae } \\
\hline Olea europaea L. & Zeytin & Food & Fruit & $\begin{array}{l}\text { The fruit is eaten by being sweetened, it is consumed by } \\
\text { turning it into oil; culture }\end{array}$ \\
\hline
\end{tabular}




\begin{tabular}{|c|c|c|c|c|}
\hline \multicolumn{5}{|l|}{ Papaveraceae } \\
\hline Papaver rhoeas L. & Gelineli & Food & Leaves & Pilaf is made; wild \\
\hline \multicolumn{5}{|l|}{ Polygonaceae } \\
\hline Polygonum aviculare L. & Başak bağı & Medicinal & Aerial parts & Used in the treatment of kidney stones by making tea; wild \\
\hline Rumex acetosella $\mathrm{L}$. & Ekșimen & Food & Leaves & Salad is made; wild \\
\hline \multicolumn{5}{|l|}{ Poaceae } \\
\hline Hordeum vulgare $\mathrm{L}$. & Arpa & Animal feed & Seed & Used as animal feed, culture \\
\hline Triticum dicoccoides (Koern.) Koern. & Buğday & Food & Seed & Used in bakery products; culture \\
\hline \multicolumn{5}{|l|}{ Punicaceae } \\
\hline Punica granatum L. & Nar & Food, medicinal & Fruit & $\begin{array}{l}\text { Fresh fruit is eaten, it is used in the treatment of diarrhea with } \\
\text { tea made of fruit husk tea; culture }\end{array}$ \\
\hline \multicolumn{5}{|r|}{ (0) } \\
\hline Paliurus spina-christi Mill. & Karaçalı & Medicinal & Fruit & Used to treat kidney disease by boiling; wild \\
\hline \multicolumn{5}{|l|}{ Rosaceae } \\
\hline Amygdalus communis L. & Badem & Medicinal, food & Fruit & $\begin{array}{l}\text { Bitter almond fruit, in the treatment of diabetes; sweet almond } \\
\text { fruit is consumed as food when it is fresh and dried; culture. }\end{array}$ \\
\hline Armeniaca vulgaris Lam. & Kayısı & Food & Fruit & It is eaten fresh and dry; culture \\
\hline Cerasus avium (L.) Moench & Kiraz & Food & Fruit & Eaten as dry and fresh; culture \\
\hline Crataegus aronia L. Bosc & Alıç & Food & Fruit & Freshly eaten, culture. \\
\hline Cydonia oblonga Mill. & Ayva & Food & Fruit & Freshly eaten, culture. \\
\hline Malus sylvestris Mill. & Elma & Food, medicinal & Fruit & $\begin{array}{l}\text { It is eaten fresh, is used in cough treatment by making tea; } \\
\text { culture }\end{array}$ \\
\hline Prunus divaricata Ledeb. & Dağ kirazı & Food & Fruit & Freshly eaten; culture \\
\hline Rosa canina L. & $\begin{array}{l}\text { Yabangülü- } \\
\text { kuşburnu }\end{array}$ & Tea-making & Fruit & Drinked as tea; wild \\
\hline Rubus idaeus L. & $\begin{array}{l}\text { Bögürtlen- } \\
\text { Ahududu }\end{array}$ & Food & Fruit & It is eaten fresh; consumed by making pastries; culture \\
\hline Rubus sanctus Schreb. & Bük & Food & Fruit & Freshly eaten; wild \\
\hline \multicolumn{5}{|l|}{ Urticaceae } \\
\hline Urtica dioica $\mathrm{L}$. & Isırgan & $\begin{array}{l}\text { Tea-making, } \\
\text { medicinal }\end{array}$ & Aerial parts & $\begin{array}{l}\text { Drinked as tea; It is used in the treatment of rheumatism by } \\
\text { turning the body into mush; wild }\end{array}$ \\
\hline \multicolumn{5}{|r|}{ 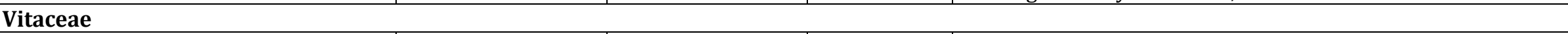 } \\
\hline Vitis vinifera $\mathrm{L}$. & Asma & Food & Leaves & $\begin{array}{l}\text { Meals are made from leaves; the fruit is consumed dry and } \\
\text { fresh; culture }\end{array}$ \\
\hline \multicolumn{5}{|l|}{ Zygophyllaceae } \\
\hline Peganum harmala L. & Üzerlik & Amulet & Seed & Ornament made from seeds is used as amulet; wild \\
\hline
\end{tabular}


In the family distribution of detected species (Fig. 2), the most commonly used families are Asteraceae and Rosaceae 10 species; Brassicaceae and Lamiaceae are 6 species; Anacardiaceae, Apiaceae, Liliaceae, Malvaceae and Moraceae are 3 species; while the other families were represented by one or two species.

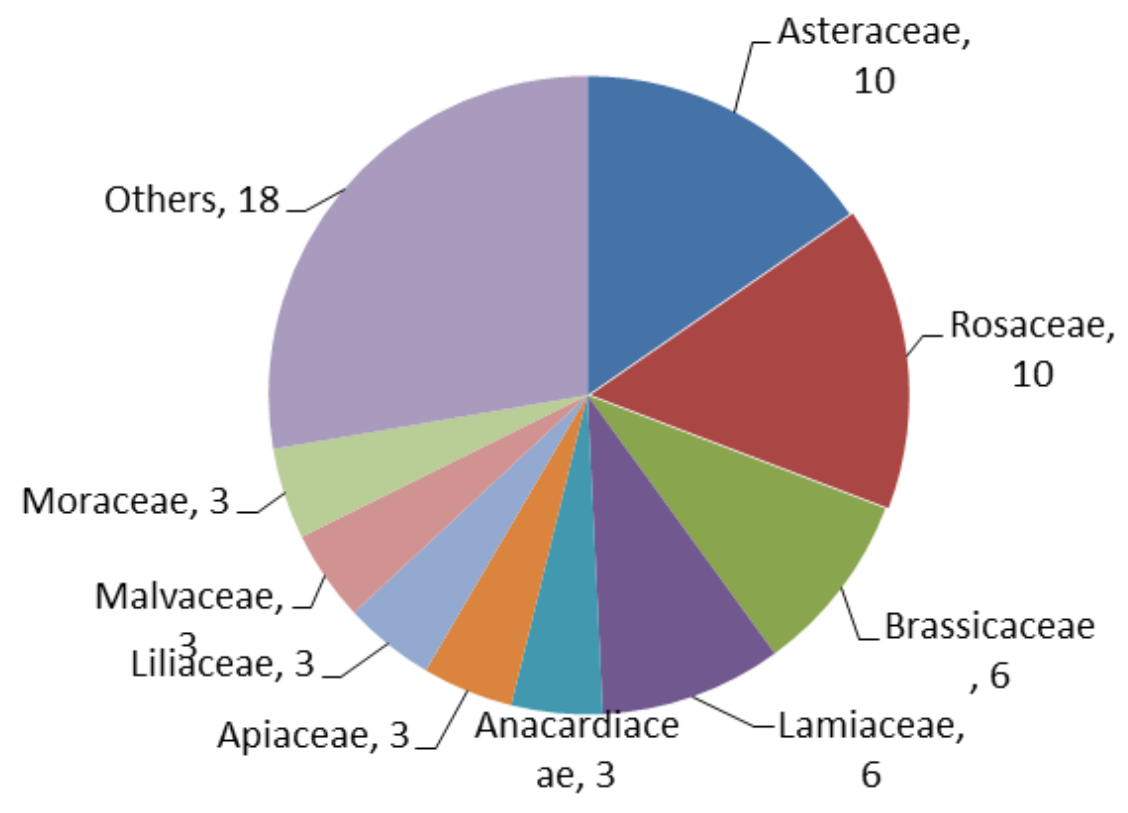

Figure 2 Distribution of traditionally used plant species to families

Most of the plants in the study area were used for food (46 species) and medicine (17 species), followed by spices ( 3 species), tea (3 species), toothpicks ( 1 species), textiles ( 1 species), fodder (1 species), chewing gum (1 species) and amulet (1 species) (Fig. 3).

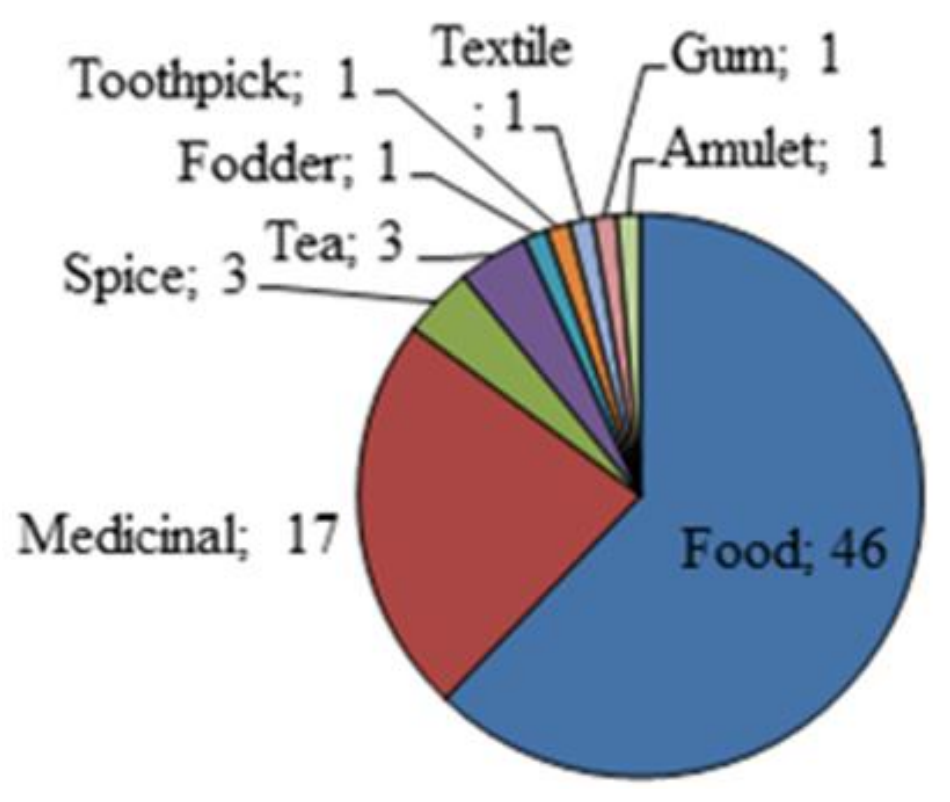

Figure 3 Distribution of plant species according to their intended use

Some photographs of the ethnobotanical plants obtained from the research area are given in figure 4 . 

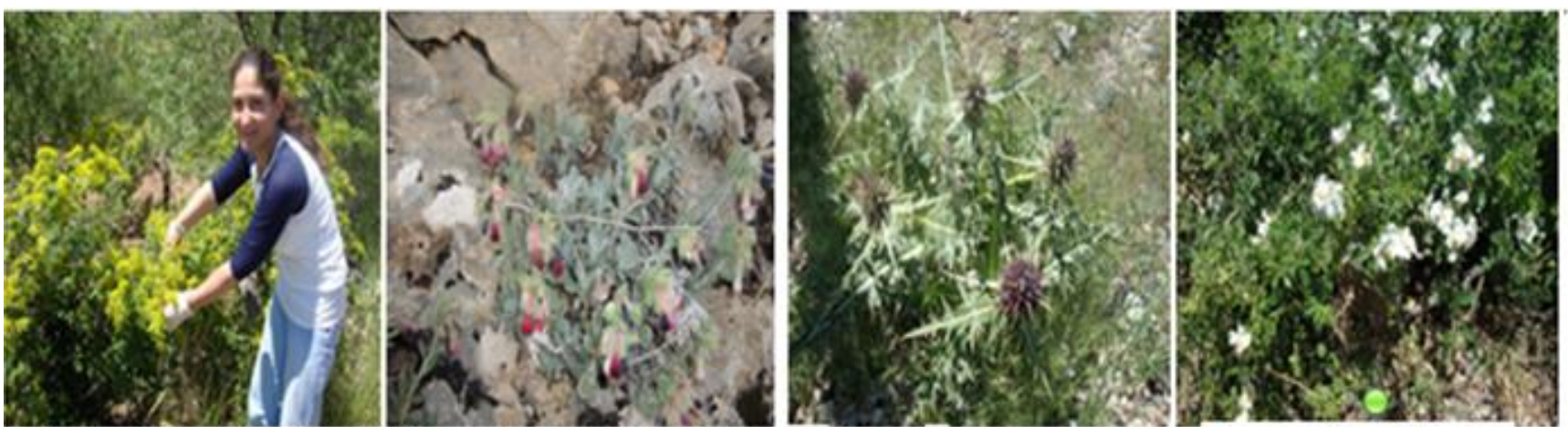

Palitorus spina-christi-Karaçalı Onosma albo-roseum-Emecele
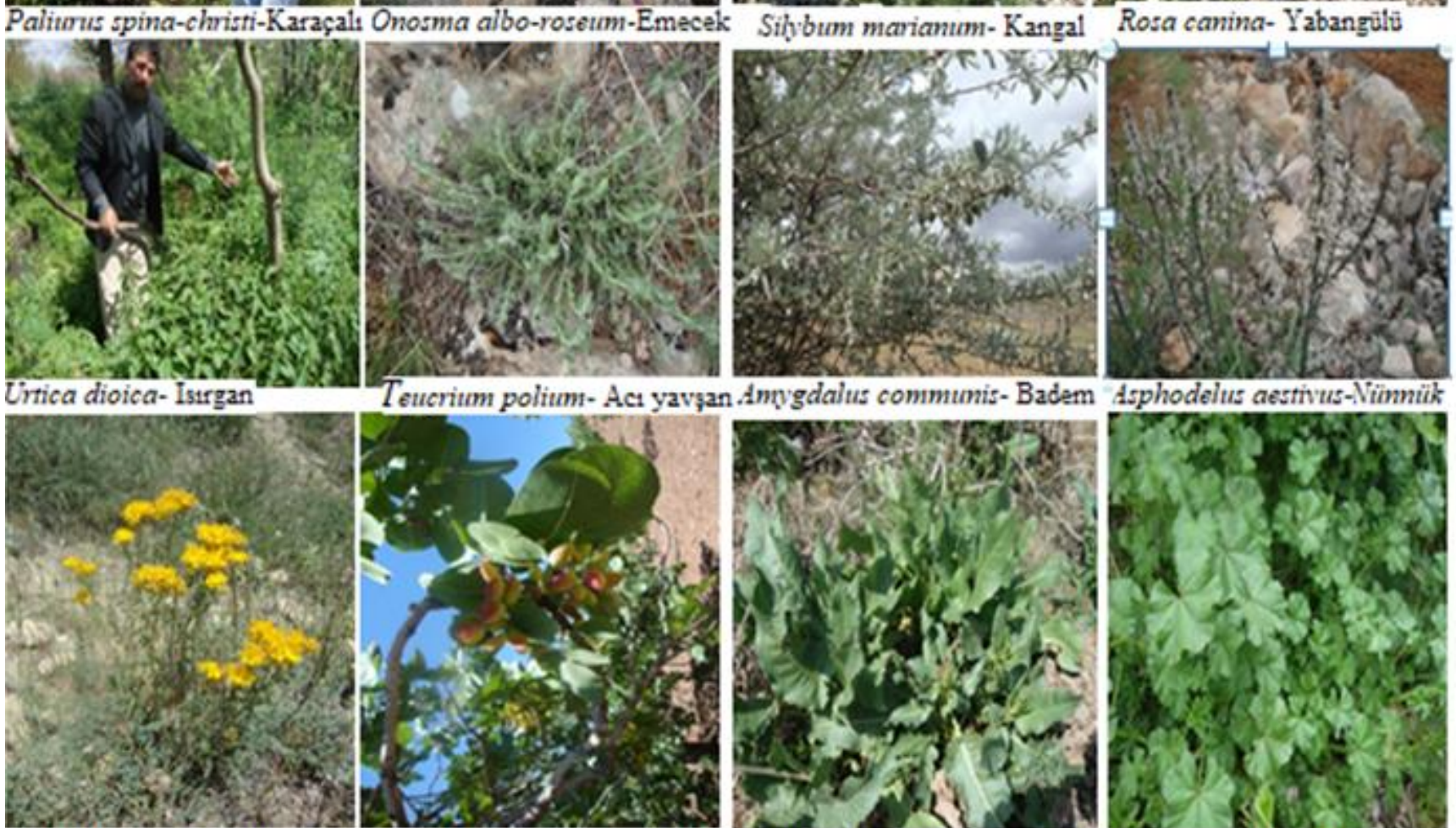

Jupericum perforatum-Kantaron Pistacia vera-Antep fistiğ:
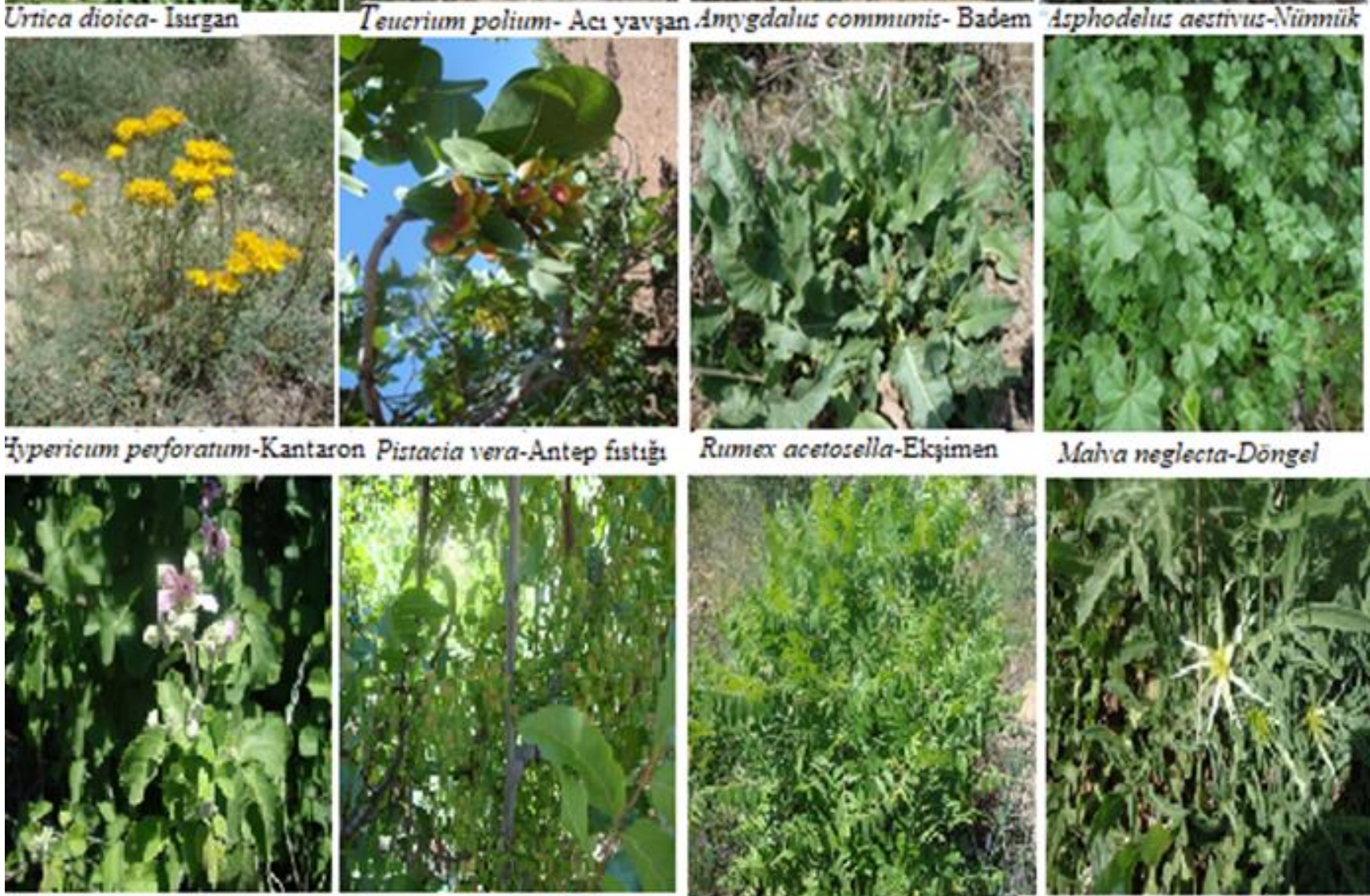

Rubus sanctus-Bük

Pistacia terebinthus-.Melengic
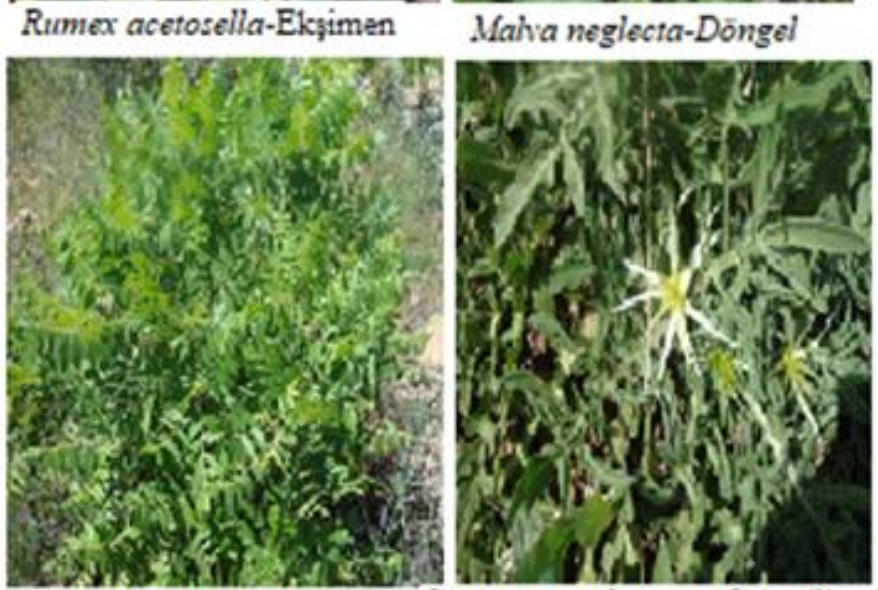

Rhus coriaria-Sumak

Centatrea calcitrapa-C,akardikeni

Figure 4 Photos of some of the plants with ethnobotanical use

The distribution of plant species according to usage purposes is $86 \%$ for food and medicine, and $14 \%$ for other uses. These ratios are a clear indication of the hope that the people of the region will benefit from natural plants in the solution of nutritional and health problems. 
Generally, most of the medicinal plants are seldom used today, and knowledge about their preparation is scarce. The knowledge about medicinal plants and their preparation is now confined mostly to old people. The younger generations are rapidly adopting the allopathic medicines, and traditional medicinal plants are now seldom used [4, 11]. The rich treasure of indigenous knowledge about local medicinal plants is therefore under threat; likely to gradually disappear with the death of older people. However, some medicinal plants such as Sideritis and Hypericum are still widely used by the local people in study area.

In order to establish a standard of medicinal plants used by the people in the region agriculture is needed. However, it is not possible to talk about any standardization of plants collected and sold today.Especially cultivation of extremely rare and endemic species collected from nature could contribute to maintain them. One way of ensuring the continuity of native plants legally collect them at the appropriate time and in moderation. A good knowledge of the interaction between with people and forests has a great importance on the efficiency and sustainability of natural areas.

\section{Compliance with ethical standards}

\section{Acknowledgments}

The authors would like to thank the Cukurova University Research Fund (Project No: FEF 2014 D1) for financial support.

\section{Disclosure of conflict of interest}

The authors declare that they have no conflict of interests.

\section{References}

[1] Cotton CM. (1996). Ethnobotany principles and applications. John Wlley and Sons, New York.

[2] Martin GJ. (2004). Ethnobotany: a methods manual. Earthscan Publications Ltd., London.

[3] Mart S and Türkmen N. (2018). A survey on wild plants with ethnobotanical use in the Bahçe and Hasanbeyli districts of Osmaniye, Turkey. GSC Biological and Pharmaceutical Sciences, 5(3), 28-35.

[4] Khan SH and Khatoon S. (2008). Ethnobotanical studies on some useful herbs of Haramosh and Bugrote valleys in Gilgit, Northern Areas of Pakistan. Pakistan Journal of Botany, 40(1), 43-58.

[5] Ertuğ F. (2000). An ethnobotanical study in central Anatolia (Turkey). Economic Botany, 54(2), $155-182$.

[6] Özgökçe F and Özçelik H. (2005). Ethnobotanical aspect of some taxa in east Anatolia (Turkey). Economic Botany, 58(4), 697-704.

[7] Arı S, Temel M, Kargığlu M and Konuk M. (2015). Ethnobotanical survey of plants used in AfyonkarahisarTurkey. Journal of Ethnobiology and Ethnomedicine, 11, 84, 1-15.

[8] Lange D. (2006). International trade in medicinal and aromatic plants: actors, volumes and commodities. In: Bogers RJ, Craker LE and Lange D (Eds.), Medicinal and aromatic plants: agricultural, commercial, ecological, legal, pharmacological and social aspects. Wageningen UR Frontis Series, Vol. 17, Springer, The Netherlands, 155170.

[9] Davis PH (Ed.). (1965-1985). Flora of Turkey and the East Aegean Islands. Edunburgh University Press, Edinburgh, Volumes 1-9.

[10] Brummitt RK and Powell CE (Eds.). (1992). Authors of plant names. Royal Botanic Gardens, Kew.

[11] Ibrar M, Hussain F and Sultan A. (2007). Ethnobotanical studies on plant resources of Ranyal Hills, District Shangla, Pakistan. Pakistan Journal of Botany, 39(2), 329-337.

\section{How to cite this article}

Özer H and Türkmen N. (2019). Investigation of plants with ethnobotanical use in Gaziantep province (Turkey). GSC Biological and Pharmaceutical Sciences, 7(2), 71-78. 